\title{
An examination of migration patterns to Ontario cities: Demarcating Ontario's periphery
}

\author{
Sean B. O’Hagan \\ Department of Geography \\ Nipissing University (North Bay, ON) \\ seano@nipissingu.ca
}

\begin{abstract}
This study sets out to determine whether similarities or differences exist in migration patterns for cities of northern Ontario and southern Ontario. Data is also grouped into large and small cities, to establish whether demographic success comes mostly from inter-or intra-regional migrants. Relevant characteristics of individuals migrating in a knowledge economy - specifically, education and employment data - are also examined. These findings are then placed within two important paradigms of economic geography: brain circulation and institutionalism. The intention is to measure migration patterns but also to use these findings to re-evaluate the core-periphery model as it applies to northern and southern Ontario.
\end{abstract}

Keywords: Ontario, migration, institutionalism, brain circulation.

\section{Résumé}

Cet article à pour objectif de déterminer si des similarités ou des différences existent dans les comportements migratoires dans les centres urbains du nord et du sud de l'Ontario. Les données sont aussi regroupées selon les grands et petits centres urbains pour établir si les succès démographiques viennent surtout des migrants interrégionaux ou intrarégionaux. Les caractéristiques pertinentes des personnes qui migrent dans une économie basée sur les connaissances, plus précisément les données sur leur éducation et leur bistorique d'emploi sont étudiées. Ces résultats sont ensuite répartis selon deux paradigmes importants de l'économie géographique, l'exode des cerveaux et l'institutionnalisme. Mon intention est de mesurer les comportements migratoires mais aussi d'utiliser ces résultats pour réevaluer le modèle périphérie-noyau tel qu'il s'applique au nord et an sud de l'Ontario.

Mots-clés : Ontario, migration, institutionnalisme, exode des cerveaux.

\section{Introduction}

The core-periphery paradigm is traditionally used to explain regional disparities in economic geography. It can be defined as a general theory of polarized growth, applicable to international, national, provincial (in Canada's case), and city levels. Regardless of the scale, core-periphery regions are generally demarcated by their economic, social, demographic, and political processes. This has led to core zones, whose development paths generally benefit from these processes, while peripheral zones do not. Innis (1956) provided 
the first real Canadian perspective on the core-periphery model through his staples thesis, where different resources lead to the emergence of regional economies throughout the country. Within Ontario, this led a number of academics (Lucas 1971; Mackenzie 1987; Kerr 1998; Yeats 1998; Polese and Shearmur 2006) to cite a sparse population and economy, dependent upon natural resources, when labelling the north as the periphery. In their assessment of Ontario, Martin, and Florida (2009: 27) conclude that the northern portion of the province (along with parts of rural Ontario and some inner-city places) is becoming increasingly disconnected from the creative economy. On the other hand, southern Ontario is considered the core, where the vast majority of people are concentrated, and manufacturing and higher-ordered services traditionally occur.

In a more recent theory, Saxenian $(2002,2006)$ suggests that "new Argonauts" can generate independent development in marginal areas, thus undermining the foundations of traditional models such as the core-periphery. She terms this concept brain circulation, whereby less developed areas can mature differently than previous theories suggest. Brain circulation refers to the circular movement of skilled labour across geographic space. It is argued that such circular movement brings intangible knowledge that proves invaluable for peripheral areas attempting to break the cycle of poverty and dependency.

The purpose of this study is to theoretically apply the underpinnings of Saxenian's concept of brain circulation to determine whether similarities or differences exist in migration patterns for selected cities of Ontario's two regions. These findings are then theoretically placed within the foundations of institutionalism. As a geographer, this author regards the concept of place as being of particular importance. Thus, special attention is directed towards the spatial configurations of migrants, in this case to Ontario Census Metropolitan Areas (CMAs) and Census Agglomerations (CAs). This is accomplished by establishing whether demographic success comes mostly from inter- or intraregional migrants. Additionally, the concept of place is related to scale. To accomplish this, city data is not only grouped into north and south, but also into large and small. Relevant characteristics of individuals migrating in a knowledge economy — specifically, education and employment data - are also examined. The intention is to measure migration patterns, but also to use these findings to re-evaluate the core-periphery model as it applies to northern and southern Ontario.

Table 1. Population increases/decreases for Ontario CMAs and CAs, 1991-2006.

\begin{tabular}{|c|c|c|c|c|c|}
\hline Geog of CAs and CMAs & 2006 population & $\begin{array}{c}1991-2006 \\
\%+\text { or - }\end{array}$ & $\begin{array}{c}2001-2006 \\
\%+\text { or - }\end{array}$ & $\begin{array}{c}1996-2001 \\
\%+\text { or }-\end{array}$ & $\begin{array}{c}1991-1996 \\
\%+\text { or - }\end{array}$ \\
\hline South & $10,300,736$ & 25.6 & 7.6 & 8.6 & 7.5 \\
\hline North & 494,410 & -3.1 & 0.8 & -4.2 & 0.3 \\
\hline South Small & 954,279 & 15.7 & 3.8 & 8.4 & 2.8 \\
\hline South Large & $9,346,457$ & 26.7 & 8.0 & 8.7 & 8.0 \\
\hline South Large (exc. TO) & $4,233,308$ & 21.7 & 6.5 & 7.3 & 6.5 \\
\hline North Small & 213,245 & -6.3 & 0.3 & -5.8 & -0.8 \\
\hline North Large & 281,165 & -0.5 & 1.3 & -3.0 & 1.2 \\
\hline Ont. CMAs and CAs & $10,795,146$ & 23.9 & 7.2 & 7.9 & 7.1 \\
\hline
\end{tabular}

SOURCE: Statistics Canada 2006, 2001, 1996, 1991. 
Table 2. Workforce distribution by sector of activity, 2006.

\begin{tabular}{lccc}
\hline \multirow{2}{*}{ Geography of CAs and CMAs } & \multicolumn{3}{c}{ Sector of Activity } \\
\cline { 2 - 4 } & Primary & Secondary & Service Prod. \\
\hline South & 1.7 & 13.7 & 78.6 \\
North & 5.9 & 10.1 & 77.8 \\
South Small & 4.1 & 10.8 & 80.5 \\
South Large & 1.5 & 14.5 & 77.8 \\
South Large (except Toronto) & 2.0 & 16.7 & 74.8 \\
North Small & 5.1 & 13.7 & 77.9 \\
North Large & 6.5 & 9.2 & 77.1 \\
Ontario CMAs and CAs & 1.9 & 13.4 & 78.7 \\
\hline
\end{tabular}

Source: Statistics Canada 2006.

\section{Development models and institutionalism}

During times of concern over inequality across the world, concepts such as the coreperiphery continue as a reference for those attempting to explain social, political, demographic, and economic variations over space. The core-periphery model is based on the notion that as one area expands in prosperity, it engulfs nearby ones to ensure continued success. The area of high growth becomes known as the core and the neighbouring areas the periphery.

Since core areas develop into cities, regions, and nations offering favourable geographic qualities, their attractiveness encourages financial and commercial flows from the periphery. In more developed economies, higher populations generally concentrate in the core, resulting in political representation being disproportionately high in these areas. The outcome is economic, social, demographic, and political advantages often favouring the interests of the core, with these areas often becoming centers of accumulation.

Traditionally this model has been used to explain the dichotomous relationship between northern and southern Ontario. A large population, as well as employment, concentrated in secondary, tertiary, and, now, quaternary and quinary sectors have made southern Ontario the core of the province. On the other hand, employment in mining and lumber has led to dependency on external forces and vulnerability in northern Ontario. In addition, sparse population densities make northern Ontario disadvantaged economically and politically.

As an introduction to the north-south disparity, Tables 1 and 2 display basic demographic and economic overviews for CMAs and CAs in the province. Table 1 presents population changes from 1991 to 2006. During this time, cities in southern Ontario grew by 26 per cent, while northern Ontario cities actually lost population. Collapsing the data reveals that large cities in southern Ontario led population growth, with a 27 per cent increase over the 15-year study period. Small cities in the south expanded as well, with a population increase of 16 per cent. Conversely, small cities in northern Ontario lost a troubling portion of their population, with most of this occurring between 1996 and 2001. Vulnerability to mining made population decreases in Elliot Lake and Timmins largely responsible for this decrease. Large northern Ontario cities also experienced a decline, albeit minor when compared to the smaller cities of the region. Still, a 0.5 per cent decrease in population is a concern. 
The purpose of Table 2 is to categorize the Ontario labour force into three economic sectors: primary, secondary, and service-producing. Both regions exhibit similar patterns for the service-producing sector, with over three-quarters of employment concentrated here. Of course, this segment of the economy has increased significantly over the past several decades as Canada has transformed from a country dominated by primary employment to one with prevailing secondary and, now, on to tertiary and quaternary employment.

The most important finding in Table 2 is the difference in primary and secondary employment between the two regions. Northern Ontario cities boast a higher percentage of workers associated with the primary sector, while in southern Ontario the secondary sector is dominant. If the data is again categorized into city size, large northern Ontario cities maintain the largest portion of primary sector employment, a direct result of Sudbury's link to the nickel industry. Conversely, large southern Ontario cities, led by Windsor with its link to the automotive industry, were most dependent on the secondary sector. Inserting these results into the context of previous research would highlight the development of southern Ontario when compared to its northern counterpart. These conclusions are drawn by broadly examining Ontario's cities. After separating the data by city size, though, even a brief review of Table 2 reveals a difference between southern Ontario's small and large cities. Results actually show small southern Ontario cities come closer to northern Ontario cities in these general economic sectors.

It has been established that results based upon a two-region analysis illustrate a demographic and economic distinction between southern and northern Ontario. Development models have picked up from results such as these to hypothesize on future economic divergences between the regions. The increasing importance of knowledge in today's competitive business climate, though, and access to more detailed data, have led academics such as Colander (2000) to propose that the research be extended in its scope of analysis. Similarly, Romer $(1986,1990)$ follows Schumpeter (1942) to propose a New Growth Theory, suggesting that fundamental theories must be changed to properly understand today's economy. Importantly, he makes the case that knowledge and intellectual capital, previously regarded as exogenous, are now being recognized as increasingly important to productivity and, therefore, to long-term regional competitiveness. Zhao et al. (2000) reveal how the Canadian economy has moved from one losing knowledge migrants through brain drain to one that now acquires migrants through brain gain. These migrants play a vital role in the economic development of the country.

Saxenian (2006) approaches her aversion to existing development models from a different perspective. Her concern with traditional theories is that at best, investment from the core might create manufacturing jobs and promote incremental development in marginal areas. The periphery is destined to remain insignificant, however, because top occupations and workers remain in the core. But as transport and communication efficiencies weaken the advantages of more developed areas, new research argues that traditional rationales for the competitiveness of cities and regions have become less persuasive.

A new body of research attempts to capture a new form of economic order that marks a dramatic shift away from the massive structures of production and the rigid labour markets associated with "Fordism." This manufacturing philosophy, which aims to achieve higher productivity by standardizing output, has impacted socioeconomic phenomena for decades. As Scott (2006: 2) suggests, actual cities are always something vastly more than just bare accumulations of capital and labor, for they are also arenas for many 
other kinds of phenomena. This collection of scholarly activity emphasizes a flow of ideas as a better rationale for cities. New economic growth theory suggests that places should be understood as centers of idea creation. If this is so, areas will grow when they are producing knowledge, or when their role as intellectual producers is increasingly important (Romer 1986, 1990; Florida 2002; Saxenian 2006). A branch of this research adopts a firm-based approach to knowledge production, by emphasizing technology use and research and development. An alternative methodology, one employed by this paper, emphasizes individuals as a starting point.

The notion of brain circulation offered by Saxenian (2002) has recently moved onto the research agenda of economic geographers. Brain circulation is sometimes referred to as the circular movement of skilled labour across nations. The concept diverges from brain drain, which earlier gained popularity to explain skilled labour emigrating from poor nations to pursue better opportunities elsewhere. But researchers (Saxenian 2002, 2006; Kuznetsov 2006) have recently made a case that brain drain is only one part of the equation. The other component relates to the social contacts and international experience that expatriates gain when working or studying in a foreign country. It is an emerging global phenomenon that is used to explain development patterns in peripheral areas, especially India, China, and Taiwan. It is argued that the circular movement brings intangible knowledge, which proves invaluable for the home country's development. Those cities, regions, and nations that do not take advantage of this flow of people (and the ideas that they bring) continuously rely on internal knowledge. Unfortunately, this insular position inevitably relegates these places to remain in the periphery. In her analysis of Silicon Valley, Saxenian (2006) shows how a number of immigrant engineers and entrepreneurs were central to the development of the region. Companies were regularly led by leaders with personal histories outside of Silicon Valley, California, and the United States. She provides well-known examples like Yahoo and Hotmail, which were started by immigrants who brought a great deal of knowledge with them to the region. Of course, she is simplifying in attributing Silicon Valley's success exclusively to migrants, when a number of other factors are important, as well.

This vein of research branches out from the concept of institutionalism, whereby mechanisms of social order govern the behaviour of individuals. Within economic geography, the institutional approach argues that regional economic differences are primarily related to inconsistencies in institutions (Saxenian 1994; Peck 2005; Hodgson 2006). This comes from institutional economics, which was pioneered by Veblen $(1904,1914)$ and focuses on understanding the role of the evolutionary process, and the role of institutions in shaping economic behaviour. Geographers, though, identify institutions as spatial compartments of socioeconomic organization and socioeconomic practices (Amin 2001).

Within this line of reasoning, Granovetter's embeddedness-network paradigm (1985) has had a tremendous influence on the institutionalist rationale of economic geography (Saxenian 1994; Storper 1997; Amin 2004; Yeung 2005). Embeddedness is the idea that economic relationships between individual actors or firms are set within social networks. While Granovetter formulated the embeddedness concept from a sociological perspective, geographers have extended the idea to include space as a vital component.

Institutions normally include formal structures at a spatial scale, such as legal rules, property laws, and government policies. But just as important, they include informal habits, codes of conduct, and organizational cultures. In other words, Ontarians are more likely to share analogous formal institutions, while informal institutions vary from region to region. Following the informal view for a moment, Scott (2001: 48) asserts that they 
are social structures that have attained a high degree of resilience. [They] are composed of cultural-cognitive, normative, and regulative elements that, together with associated activities and resources, provide stability and meaning to social life.

These social structures are both forced upon and followed by individuals within an area. Institutions are embedded into individuals and then, through the socialization process, newer ones are continuously reproduced. Important to the theoretical foundations of this paper, institutions must be incessantly introduced from external areas to ensure continual progress to compete globally. If institutions are not frequently renewed, a region is likely to lag in development. For this reason, in-migrants are beneficial, as they introduce new institutions and are more likely to question existing ones. Additionally, exposure to inmigrants is likely to cause people already living in an area to question existing institutions.

Turning to northern Ontario, while the region would not be considered analogous to entire countries like India and China, elements of the brain circulation hypothesis can still be applied. Importantly, the intention here is not to try to place the present research fully into context of Saxenian's brain circulation; while the notion is applied to high-end technical workers and returning migrants, this article essentially adopts a somewhat different approach. By examining the geography of in-migrants to CMAs and CAs, the purpose is to compare the origin of northern Ontario migrants to that of southern Ontario migrants. These findings are then placed within the foundations of institutionalism. Do cities in each of these regions obtain a sufficient proportion of their migrants from external sources to guarantee that new knowledge and institutions are continually being introduced to these areas? Perhaps just as important, are the kinds of incoming migrants valuable in a knowledge economy?

\section{Data and its limitations}

In 2006 Ontario possessed a total 43 CMAs and CAs. Of these, 8 were identified as being located in northern Ontario, with the remaining 35 in the southern part of the province. For the purposes of this study, the cities are categorized as large (those with a population of at least 100,000 in the 2006 Census) and small (those with a population between 10,000 and 100,000). These were selected to follow Statistics Canada's $\mathrm{CMA}$ and CA categories. Additionally, the rationale for separating the data into these two groups lies in the existing scholarship on Canadian migration. A large volume of research has been conducted on Canadian immigration (Kalbach 1970; Badets and Chui 1994; Li 2002; Beach et al. 2003; Reitz 2004; Chui et al. 2008), inter-provincial migration (Anderson 1966; Courchene 1970; Robinson and Tomes 1982; Newbold and Liaw 1994; Finnie 1999, 2004; Basu and Rajbhandary 2006; Coulombe 2006), and internal migration (George 1970; Kobayashi and Peake 1997; Ley 1999; Murdie 1998; Hiebert 1999, 2000, 2005). Unfortunately, an overwhelming portion of these studies focus on large cities. As suggested by Hiebert (2000: 40), even though the scholarship on Montreal, Toronto, and Vancouver is extensive, other urban centres have hardly been addressed. While he refers to significant gaps in the literature focussing on cities such as Ottawa, the coverage becomes even less extensive for urban centres at the CA level, especially if they are in "marginal" areas. Access to small city data is not as readily available, however, making research more difficult and less likely. The premise of this paper argues that a comparison of Ontario's large and small cities offers a more thorough avenue to evaluate the coreperiphery as it relates to the province. 
To measure migration in Canada, researchers commonly utilize mobility data from the Long Form Census. The Short Form contains 8 questions, while the Long Form includes 53. This makes the Long Form Census more costly, and as a result it is distributed to only 20 per cent of the population. Thus, it is important to note that the remainder of this paper utilizes this sample of migrants. In the Long Form, the mobility question asks for the place of residence five years ago. In-migrants are defined as those individuals now residing in one of the CMAs or CAs but not living in those cities five years earlier. Relevant characteristics of these people are based on an analysis of microdata for cities in consecutive (5-yearly) censuses from 1991 to 2006.

There are limitations of the study worth mentioning here. Importantly, in-migrants of less than five years, as well as returning migrants, are not addressed. They could be, as migrants of one year are collected by Statistics Canada. But they are not presented in this study, as this data is only available from 1996 onwards at the required level of geographical detail. It was determined that revealing temporal changes at the CMA and CA level over a longer time period was an important construct with respect to the theoretical arguments.

\section{Results}

As a starting point, income is considered for its obvious links to economic growth, as well as to the development theories explained earlier. It is also used for its noted connection to migrants, and particularly immigrants. Income levels, especially the low economic outcomes among immigrants entering Canada during the 1990s, incited policy debate and consequent research. Understandable reasons, such as language and education, were cited as explanations for lower incomes (Aydemir and Skuterud 2005; Picot and Sweetman 2005). Within the context of a knowledge-based economy, immigrant selection procedures were altered to directly increase the education and language skills of immigrants, while indirectly increasing incomes. Although internal migrants do not encounter the same hurdles as their international counterparts, the idea remains the same. Individuals with higher incomes are expected to be a more positive influence on urban economic growth. The variable total income was used because it amalgamates income from a number of sources, such as wages, salaries, and age security pensions. For comparison purposes, all income levels are measured against the base year of 2002.

Table 3. Average Income of In-Migrants to Ontario CMAs and CAs, 1991-2006.

\begin{tabular}{lllll}
\hline \multicolumn{1}{c}{\begin{tabular}{c} 
Geography of CAs and \\
\multicolumn{1}{c}{ CMAs }
\end{tabular}} & \multicolumn{4}{c}{ total income (adjusted to 2002 dollars) } \\
\cline { 2 - 5 } & 1991 & 1996 & 2001 & 2006 \\
\hline South & 27,375 & 23,947 & 27,721 & 28,194 \\
North & 22,610 & 20,027 & 20,615 & 22,732 \\
South Small & 23,022 & 20,898 & 23,074 & 25,035 \\
South Large & 28,309 & 24,570 & 28,829 & 29,038 \\
South Large (except Toronto) & 26,879 & 23,439 & 27,118 & 28,033 \\
North Small & 21,663 & 19,705 & 20,877 & 22,423 \\
North Large & 23,717 & 20,389 & 20,403 & 22,996 \\
Ont. CMAs and CAs & 27,130 & 23,670 & 27,324 & 27,899 \\
\hline
\end{tabular}

SOURCE: Statistics Canada 2006, 2001, 1996, 1991. 


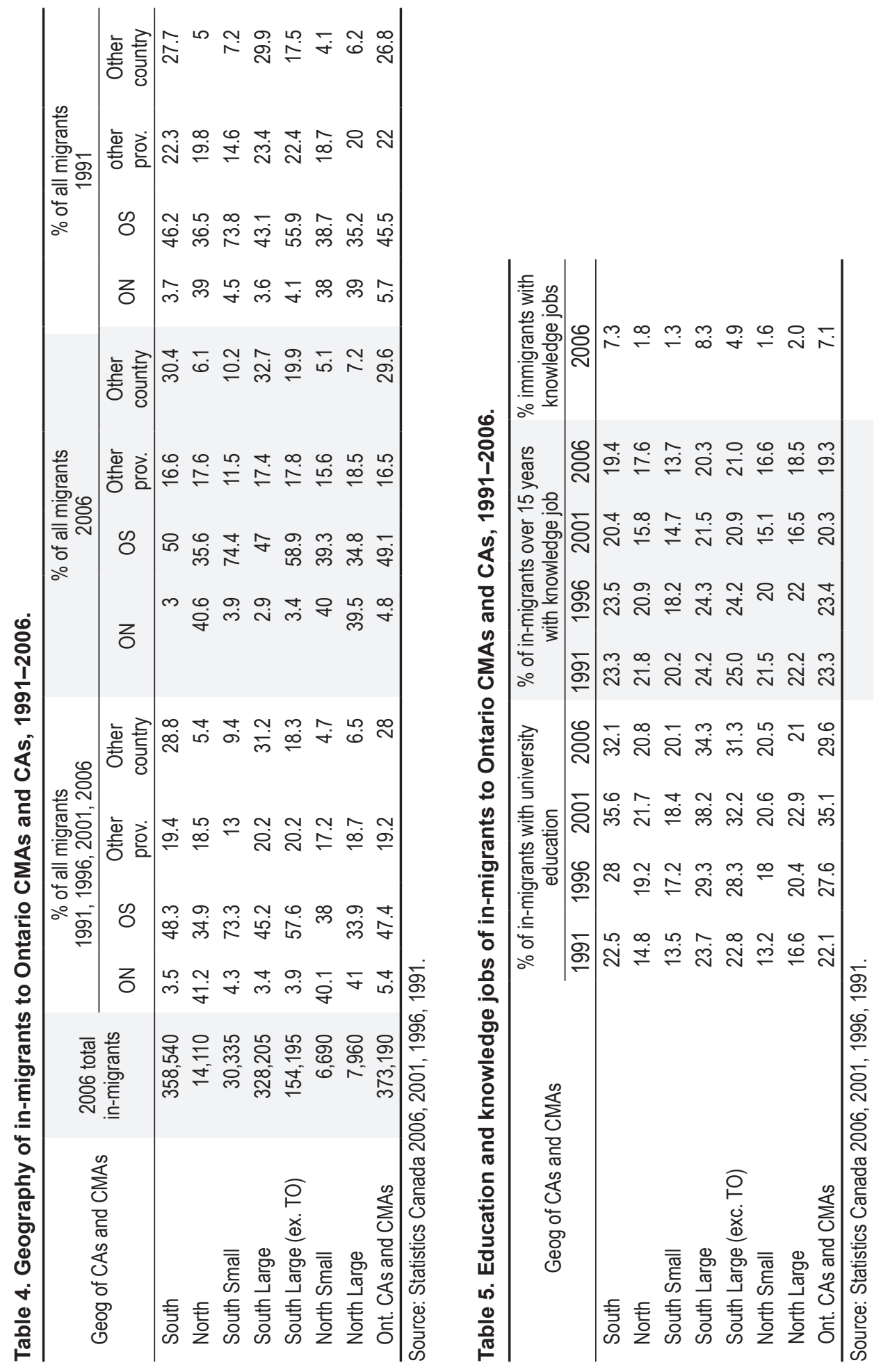


Table 3 reveals that migrants to all city categories experienced similar patterns for total income over the study period. Each decreased from 1991 to 1996 before steadily increasing from 1996 to 2006. While these income levels are not standardized for cost of living, they indicate a difference between northern and southern Ontario cities. A t-test verifies this difference between the two groups for each census year (all at $\mathrm{P}<0.001$ ). Separating the data into city size reveals that the total incomes for large cities in southern Ontario are substantially higher than the other categories. Small cities in southern Ontario maintain a similar pattern to northern Ontario large cities in 1991 and 1996, before increasing to a further extent in the final two census periods. Finally, small cities in northern Ontario possess the lowest per capita incomes (with the exception of 2001). This statistic is influenced by the outlier Elliot Lake, now converted to a retirement community whose migrants depend on old-age security pensions. After taking out the large city data, ANOVA tests were applied to the remaining three groups, one for each census year. No significant difference was found for 1991 and 1996. However, in 2001 and 2006 there was a difference $(\mathrm{P}<0.001)$, no doubt as a result of small southern Ontario cities' larger incomes.

At this time, the paper attempts to place a greater emphasis on theoretically applying Saxenian's concept of brain circulation to in-migration in the CMAs and CAs of Ontario. Table 4 shows the geography of in-migrants, separated into intraregional, intraprovincial, interprovincial, and immigration. An initial item worth mentioning is the extreme difference in the total number of in-migrants between northern and southern CMAs and CAs. Therefore, utilizing the percentage of all migrants allows for a more meaningful comparison between the two regions.

The most noteworthy revelation is the importance of intra-regional migrants. This is especially true for southern Ontario's small cities, where over 80 per cent of in-migrants come from other parts of southern Ontario. Large cities of southern Ontario also receive a large portion of their in-migrants intra-regionally, but at 65 per cent in 1991 and 70 per cent in 2006, this is a comparatively smaller reliance. While northern Ontario also obtained a large amount of intra-regional migrants, a 43 per cent average over the four censuses, the dependence is less than southern Ontario because of the smaller population to draw from. Both small and large cities in northern Ontario rely equally on intraregional migrants. The results for all cities agree with previous migration research, in that most moves occur over shorter distances. This occurs for a number of reasons. First, the shorter distance affords individuals greater access to information on opportunities of the destination. Additionally, migrants make this decision based on the fact that they already share many of the institutions with people in the place they are moving to. From a regional development perspective Saxenian would argue that, all other things being equal, new institutions and knowledge are less likely to be brought by these migrants.

Most relevant to the concept of brain circulation in Table 4 are the results regarding migrants from other provinces and immigrants. In this category, a significant difference exists between city sizes and regions. Southern cities obtain a greater portion from this group of migrants, with large cities greatly impacting these results. Small cities in southern Ontario, on the other hand, received a much smaller portion of their migrants in this manner, with 13 per cent of all migrants originating from other provinces and 9 per cent from other countries, when all four censuses are taken into account. Importantly, though, there is a decrease in interprovincial migrants from 15 to 12 per cent and an increase in immigrants from 7 to 10 per cent to small cities in southern Ontario over time. 
In northern Ontario, both classes of cities are fairly consistent in the area of origin of their migrants. Large cities received 7 per cent of total in-migrants from other countries in 2006, up from 6 per cent in 1991. Small cities in northern Ontario received 5 per cent of their in-migrants from other countries in 2006, up from 4 per cent in 1991. Northern Ontario large cities obtain close to 19 per cent of total migrants inter-provincially over the four census periods while for small cities this was 17 per cent.

For the purpose of theoretically examining brain circulation and the importance of institutionalism, the categories of interprovincial migration and immigration were amalgamated, with an interesting pattern emerging. Small cities in southern Ontario, with 22 per cent, display a geographical pattern of source migrants similar to both large (25 per cent) and small cities (22 per cent) in northern Ontario over the four census periods. On the other hand, in southern Ontario's large cities over 50 per cent of migrants come from these two sources. Even excepting the influence of Toronto, the remaining large cities of southern Ontario are distinct from other city classes. Given that Table 4 uses categorical data, a Mann-Whitney test was used. This revealed a statistically significant difference in the area of origin of southern and northern Ontario CMA and CA migrants (all at P < 0.001). Again, large city data were dropped to compare the three remaining city classes. Here a Chi-square was used, which verified a significant difference between groups in 1991, 1996, and 2006 ( $\mathrm{P}<0.001$ ) but not in 2001. This can most likely be attributed to northern Ontario's large cities obtaining a slightly greater percentage of inter-provincial migrants and immigrants. Returning to the theoretical argument of the paper, institutions must continuously be introduced from external areas to ensure continual progress. If institutions are not frequently renewed, a region is likely to lag in development. The results presented here suggest that southern Ontario's large cities are in a superior position, moving forward to compete in today's global economy.

Moving to educational attainment, notable economic development scholars (Brown and Lauder 1997; Bradshaw and Blakely 1999; Blakely and Green Leigh 2010) highlight this element as perhaps the most critical to future urban prosperity. Skills, in large part obtained through education, have assumed strategic importance in securing an advantage in today's knowledge economy. Information indicating the person's highest education is obtained from the educational qualifications question, which asks for all certificates, diplomas, and degrees to be reported. There is an implied hierarchy in this variable, with this study using the highest level, "percentage of individuals with a university degree." Returning to the earlier theoretical discussion of Saxenian's brain circulation, these results dispute a core-periphery analogy based upon a north-south division. Rather, they reveal southern Ontario's large cities in an advantageous position when compared to the remaining three city classes.

By simply dividing data into "north" and "south," Table 5 reveals that both regions received an increasing percentage of migrants with post-secondary education from 1991 to 2001, with a slight drop by 2006. However, applying a Mann-Whitney test reveals a difference for all years (all at $\mathrm{P}<0.001$ ), whereby a much greater percentage of southern Ontario migrants had a post-secondary school education. Again, separating the cities into large and small reveals the same pattern as the geographic query earlier. A much higher percentage of migrants to southern Ontario's large cities possesses a university education when compared to the other three categories. Migrants to small cities in southern Ontario possess a similar amount of university-based education as northern Ontario's large and small cities. Again, to verify this hypothesis, large city data were taken out and 
a Chi-square test applied to the remaining three groups; the only significant difference was found for the year 1991 ( $\mathrm{P}<0.05)$. Table 5 shows that in 1991 migrants to northern Ontario's small cities lagged in their educational attainment, especially when compared to northern Ontario's large cities. Again, applying the brain circulation argument, we may dispute the labelling of the southern portion of the province as the "core" and the northern portion of the province as the "periphery."

If urban growth theory now stresses the importance of places as centers of idea creation, then cities should grow when their role as knowledge producers becomes increasingly important. But how is knowledge production quantified? As suggested by Baldwin and Beckstead (2003), there is no perfect measure. This paper adopts a labour market perspective by using employment to determine which geographical areas receive knowledge migrants. To measure knowledge employment concentration, this study uses a method proposed by Beckstead and Vinodrai (2003). They define 40 out of a possible 132 job categories of the three-digit National Occupational Categories as being knowledge related. Knowledge migrants were calculated as the percentage of total migrants employed in a knowledge job during the current census.

Table 4 reveals that those involved in knowledge jobs constitute a modest percentage of total migrants for all cities. More worrisome is the fact that knowledge workers as a percentage of all migrants actually decreased over time. Migrant knowledge workers to large southern Ontario cities make up the largest grouping, at 20 per cent. But this number has dipped from a high in 1996, when 24 per cent of all migrants were employed in a knowledge job.

Here is the first case where a statistical difference was not apparent for every census period when comparing the broad categories of north and south cities. A Mann-Whitney test found no statistical difference for 1991 but a difference for $1996(\mathrm{P}<0.05)$ as well as 2001 and 2006 ( $\mathrm{P}<0.001)$. As one can see in Table 4 though, this outcome is attributable to southern Ontario's small cities. Knowledge employment in small southern Ontario cities is the lowest, at 14 per cent in 2006. This is a large decrease, from 20 per cent in 1991. Northern Ontario cities fall between, with 17 per cent of all small-city migrants in knowledge jobs and 19 per cent in large cities for the year 2006. Similar to southern Ontario cities, though, these percentages have decreased from their highs in the 1990s. Once again, the large city data for southern Ontario was omitted, and a Chi-square test performed. The only significant difference found was for the year 2006 ( $\mathrm{P}<0.001$ ), when migrants to southern Ontario's small cities composed the least percentage of knowledge migrants.

The final column of Table 4 presents the percentage of immigrants possessing knowledge jobs for 2006. The results are remarkably insignificant. This suggests that even though changes were made to immigration policy to augment the number of immigrants to Canada perceived as effective in a knowledge economy, this has not materialized. Secondly, Table 2 further reinforces the pattern of results. Southern Ontario's large cities are distinct in their ability to attract immigrants employed in knowledge jobs. Meanwhile, southern Ontario's small cities are similar to northern Ontario's large and small cities in their (in)ability to attract these highly sought-after immigrants. Again, a Mann-Whitney test revealed a difference between southern and northern Ontario $(\mathrm{P}<0.001)$ cities, but when large-southern-city data were omitted, a Chi-square test found no statistical difference between southern Ontario's small cities, northern Ontario's large cities, and northern Ontario's small cities. 


\section{Discussion: Implications of migration patterns on economic and urban development in Northern Ontario}

Given the attention that has been focused on the knowledge economy, it should come as no surprise that there is a lively debate over the labelling of northern Ontario as a peripheral region in comparison to its southern counterpart. While Martin and Florida (2009) point out that the region is becoming "increasingly disconnected," which will eventually result in a dwindling of high-end workers as well as general population in northern Ontario over time, other academics (Hall and Donald 2009; Robinson 2009) have come to the region's defence. Robinson (2009) suggests that northern Ontario should be allowed to build upon its competitive advantage in the forestry and mining sectors, to grow its largest centres. Hall and Donald (2009) counter Florida's argument as well, pointing out that companies do have the potential to thrive in the periphery, and possible details about innovative and creative enterprises in traditional and emerging sectors of northern Ontario. It is important to note that the focus of both Robinson and Hall's arguments surround a small number of companies, industries, and cities that are in advantageous positions.

There are a number of ways to measure the well-being of cities. For example, comparing employment sectors, standardized incomes, and population growth (or lack of growth) has been a conventional method for an extended period of time. In this sense there is a sizeable disparity between northern and southern Ontario. This evaluation formula is of course changing, with variables that influence the future development of cities in a knowledge economy taking on a greater magnitude in this discussion.

By shifting the scale of analysis from the regional level to the size of the city, as well as adding employment and education characteristics of individuals, the results presented in this paper suggest that our conventional understanding of a north-south dichotomy is not as clear as broader analyses suggest. By applying the theoretical arguments of institutionalism and brain circulation to small and large cities, one can see that the differences between the two regions are mainly explained by the large centres of southern Ontario. Additionally, space does not permit the inclusion of other variables analyzed by the researcher that are less connected to the knowledge economy, such as age and sex. Suffice it to say that each variable reveals little difference between southern Ontario's small cities and northern Ontario's large and small cities.

Given the renewed interest in quality of place as a key attribute in the knowledgeeconomy, it is not surprising that most of the research has tended to focus on these large metropolitan areas. In this discussion northern Ontario's large cities often lag behind other CMAs across the country. In terms of the importance of place, Coish's examination of Census Metropolitan Areas as culture clusters (2004), which measures niche clusters of arts and culture industries, and Gertler et al.'s Creativity and the Bohemian Index (2002), which charts the concentration of working artists, musicians, writers, designers, and entertainers across metropolitan areas, are just two examples where Sudbury and Thunder Bay perform close to the bottom of the national hierarchy.

Northern Ontario still possesses a resource-based economy that is highly capital intensive and will become more so in the future. It is this capital intensity that makes the region competitive globally. If the capital intensity continues to increase and these sectors become more mechanized, then labour will fall. Since this labour force serves as the base for the economy in the north, it will become difficult to possess more knowledge-creating 
jobs. But the results revealed here suggest that the policy targeted at aiding northern Ontario has placed both large and small cities of the region in a comparable position to southern Ontario's small cities. Applying the concept of brain circulation suggests that the large cities in southern Ontario are in a superior position, moving forward in today's global economy, with all three other city categories lagging in competitiveness. Validating this argument is the greater dependency of southern Ontario's small cities and northern Ontario's large and small cities on inter-regional migrants. This result, along with education and employment findings, reveals that southern Ontario's large cities can take advantage of the increased exposure to institutions that the other cities cannot.

Perhaps the core-periphery relationship between the regions of northern and southern Ontario is better explained at a smaller geographic scale. On the one hand, policy shifts in service provision have created a pattern of advantaged regional centres putting northern Ontario cities on a par with southern Ontario's small cities, moving forward in a knowledge economy. On the other, the results found here actually reinforce the coreperiphery model. They suggest that Ontario's dichotomous relationship can be better explained at an urban level, irrespective of geography. The core-periphery of Ontario has Toronto as its nucleus, other large southern Ontario cities as a second tier, followed by a third level composed of small southern Ontario cities as well as large and small northern Ontario cities. This third tier of cities provides services to outlying areas involved in industries that are becoming more capital-intensive or are moving offshore.

\section{Conclusion}

A fundamental concern for policymakers interested in promoting economic development and growth is determining the competitiveness of cities. This can be accomplished in a number of ways, one of which is acquiring a population base that is useful in today's knowledge economy. Typical discussions on this topic rightly characterize southern Ontario cities in an advantaged position and northern Ontario cities in a disadvantaged one.

Drawing on evidence found in this paper, we challenge the prevailing perception that northern Ontario as a whole will be left behind southern Ontario as a whole in today's knowledge economy. We argue that drawing conclusions at these broad geographic scales is problematic. By simply altering the geographic level of analysis, southern Ontario's small cities are more on a par with northern Ontario's small and large cities than is commonly reported.

The purpose of this paper is not to argue that northern Ontario is well positioned for the future in a knowledge economy. Quite the contrary: losing population over this 15 -year study period is an extremely troubling occurrence. For example, North Bay firms recently informed their mayor that a lack of trained individuals to replace retiring baby boomers may force them to relocate their offices in the coming decades (Dale 2010). Additionally, an economy served by a primary resource base will perpetuate regional vulnerability in a knowledge economy.

The intention of this paper is to show how a few variables associated with the knowledge economy indicate that large southern Ontario cities, especially Toronto, are statistically different from other cities in the province. On the other hand, small southern Ontario cities share a commonality with small and large northern Ontario cities. Broad demographic and economic variables such as population change and total incomes do in- 
deed suggest that southern Ontario's small cities are different than northern Ontario cities. But further investigation into variables on migrants relevant in a knowledge economy, such as education level and percentage of workers in knowledge employment, reveals that these cities are more similar than is generally stated.

The results of this study generate further research questions that need to be addressed. A logical next step is to reach these migrants, especially those in southern Ontario's small cities as well as northern Ontario's large and small cities, and specifically ask why they chose the location they selected. Were they attracted to the amenities of a specific city? Or did they leave a place because it lacked amenities they required? From a geographer's perspective, it is perhaps more interesting to establish the relationship between migrants and city size than to broadly categorize these individuals moving to northern or southern Ontario urban centres. Geographers have a unique opportunity to contribute to regional economic development efforts through such targeted research.

\section{References}

Amin, A. 2001. Moving on: Institutionalism in economic geography. Environment and Planning A 33:1237-41.

. 2004. An institutionalist perspective on regional economic development, in Reading Economic Geography, edited by T.J. Barnes, J. Peck, E. Sheppard, and A. Tickell. Victoria (Australia): Blackwell Publishing, pp. 48-58.

Aydemir, A. and M. Skuterud. 2005. Explaining the deteriorating entry earnings of Canada's immigrant cohorts: 1966-2000. Analytical Studies Research Paper Series (Catalogue No. 11F0019MIE2004225). Ottawa: Statistics Canada.

Anderson, I.B. 1966. Internal Migration in Canada, 1921-1961. Economic Council of Canada, Staff Study No. 13. Ottawa: The Queen's Printer.

Badets, J. and T. Chui. 1994. Canada's Changing Immigrant Population. Ottawa: Statistics Canada.

Baldwin, J. and D. Beckstead. 2003. Knowledge workers in Canada's economy, 1971-2001: Insights on the Canadian economy (Catalogue No. 11-624-MIE2003004). Ottawa: Statistics Canada, Analytical Studies Branch.

Basu, K. and S. Rajbhandary. 2006. Interprovincial migration of physicians in Canada: What are the determinants? Health Policy 76(2):186-93.

Beach, C.M., A.G. Green, and J.G. Reitz. 2003. Canadian Immigration Policy for the 21 st Century. Kingston, ON: Queen's University School of Policy.

Beckstead, D. and T. Vinodrai. 2003. Dimensions of Occupational Changes in Canada's Knowledge Economy, 1971-1996. The Canadian Economy in Transition Research Paper Series (Catalogue No. 11-622-MIE2003004). Ottawa: Statistics Canada.

Blakely, E. and N. Green Leigh. 2010. Planning Local Economic Development. 4th edn. Thousand Oaks, CA: Sage.

Bradshaw, T. and E. Blakely. 1999. What are third-wave state economic development efforts? From incentives to industrial policy. Economic Development Quarterly 13:229-44.

Brown, P. and H. Lauder. 1997. Education, globalization, and economic development. Journal of Educational Policy 10(1):1-24.

Chui, T., K. Tran, and H. Maheux. 2008. Immigration in Canada: A Portrait of the Foreign-born Population, 2006 Census. Ottawa: Statistics Canada.

Coish, D. 2004. Census Metropolitan Areas as Culture Clusters: Trends and Conditions in CMAs. Ottawa: Statistics Canada.

Colander, D. 2000. The death of neoclassical economics. Journal of the History of Economic Thought 22:127-43. 
Coulombe, S. 2006. Internal migration, asymmetric shocks, and interprovincial economic adjustments in Canada. International Science Review 29(2):199-223.

Courchene, T. 1970. Interprovincial migration and economic adjustment. Canadian Journal of Economics 3:550-76.

Dale, D. 2010. \$270,000 website aims to attract immigrants. North Bay Nugget, January 11.

Finnie, R. 1999. Inter-provincial migration in Canada: A longitudinal analysis of movers and stayers and the associated dynamics. Canadian Journal of Regional Science 22(3):227-62.

- 2004. Who moves? A panel logit model analysis of inter-provincial migration in Canada. Applied Economics 36(16):1759-79.

Florida, R. 2002. The Rise of the Creative Class. New York: Basic Books.

George, M.V. 1970. Internal Migration in Canada. Ottawa: Dominion Bureau of Statistics.

Gertler, M., R. Florida, G. Gates, and T. Vinodrai. 2002. Competing on Creativity: Placing Ontario's Cities in North American Context. Toronto: Ontario Ministry of Enterprise, Opportunity and Innovation and the Institute for Competitiveness and Prosperity.

Granovetter, M. 1985. Economic action and social structure: The problem of embeddedness. American Journal of Sociology 91:481-510.

Hall, H., M. and B. Donald. 2009. Innovation and Creativity on the Periphery: Challenges and Opporunities in Northern Ontario. Toronto: Martin Prosperity Institute, Rotmans School of Management. http://martinprosperity.org/media/pdfs /Innovation_and_creativity_on_the_ Periphery-H_Hall-B_Donald.pdf (retrieved May 5, 2010).

Hiebert, D. 1999. Immigration and the changing social geography of greater Vancouver. BC Studies 121:35-82.

. 2000. Immigration and the changing Canadian city. Canadian Geographer 44(1):25-43.

2005. Migration and the Demographic Transformation of Canadian Cities: The Social Geography of Canada's Major Metropolitan Centres in 2017. Working Paper No.05-14. Vancouver: RIIM.

Hodgson, G. 2006. What are institutions? Journal of Economic Issues 40:2-4.

Innis, H. 1956. The teaching of economic history, in Essays in Canadian Economic History, edited by M. Innis. Toronto: University of Toronto Press, pp. 3-16.

Kerr, D. 1998. Emergence of the Industrial Heartland, c. 1760-1960, in Heartland and Hinterland: Geography of Canada, edited by L. McCann and A. Gunn. Toronto: Prentice Hall, pp. 74-108.

Kalbach, W. 1970. The Impact of Immigration on Canada's Population. Ottawa: Dominion Bureau of Statistics.

Kobayashi, A. and L. Peake. 1997. Immigration and Canadian Cities: A Critical Review of Literature and Annotated Bibliography from the Perspective of Urban Studies. Ottawa: Citizenship and Immigration Canada.

Kuznetsov, Y. 2006. Diaspora Networks and International Migration of Skills: How Countries Can Draw on their Talent Abroad. New York: WBI Development Studies.

Ley, D. 1999. Myths and meanings of immigration of and the metropolis. The Canadian Geographer 43:2-19.

Li., P.S. 2002. Destination Canada: Immigration Debates and Issues. Don Mills, ON: Oxford University Press.

Lucas, R. 1971. Minetown, Milltown, Railtown: Life in Canadian Communities of Single Industry. Toronto: University of Toronto Press.

Mackenzie, S. 1987. Neglected spaces in peripheral places: Homeworkers and the creation of a new economic centre. Cahiers de geographie du Quebec 31:247-60.

Martin, R. and R. Florida. 2009. Ontario in the Creative Age. Toronto: Martin Prosperity Institute, University of Toronto Rotman School of Management.

Murdie, R.A. 1998. The welfare state, economic restructuring and immigrant flows: Impacts on sociospatial segregation in Greater Toronto, in Urban Segregation and the Welfare State: Inequality and Exclusion in Western Cities, edited by S. Musterd and W. Otendorf. London: Routledge, pp. 64-93. 
Newbold, B. and K. Liaw. 1994. Return and onward interprovincial migration through economic boom and bust in Canada from 1976-81 to 1981-86. Geographical Analysis 26(3):228-45.

Peck, J. 2005. Economic sociologies in space. Economic Geography 81:127-76.

Picot, G. and A. Sweetman. 2005. The deteriorating economic welfare of immigrants and possible causes: Update 2005. Analytical Studies Research Paper Series (Catalogue No. 11F0019MIE2005262). Ottawa: Statistics Canada.

Polese, M. and R. Shearmur. 2006. Why some regions will decline: A Canadian case study with thoughts on local development strategies. Papers in Regional Science 85(1):23-46.

Reitz, J.G. 2004. Canada: Immigration and nation-building in the transition to a knowledge economy, in Controlling Immigration: A Global Perspective, edited by W. Cornelius, P. Martin, J. Hollifield, and T. Tsuda. 2nd edn. Stanford, CA: Stanford University Press, pp. 97-133.

Robinson, D. 2009. Northern Ontario in the Creative Age. Northern Ontario Business. Sudbury. ON. http://www.northernontariobusiness.com/columns/robinson/Northern-Ontario-in-thecreative-age.aspx (retrieved May 10, 2010).

Robinson, C. and N. Tomes. 1982. Self selection and interprovincial migration in Canada. Canadian Journal of Economics 15(3):474-502.

- 1990. Endogenous technical change. Journal of Political Economy 98: S71-S102.

Romer, P. 1986. Increasing returns and long run growth. Journal of Political Economy 94:1002-37.

Saxenian, A. 1994. Regional Advantage: Culture and Competition in Silicon Valley and Route 128.

Cambridge, MA: Harvard University Press.

. 2002. The Silicon Valley connection: Transnational networks and regional development in Taiwan, China, and India. Science, Technology, and Society 7:117-49.

- 2006. The New Argonauts: Regional Advantage in a Global Economy. Cambridge, MA: Harvard University Press.

Schumpeter, J. 1942. Capitalism, Socialism, and Democracy. New York: Harper.

Scott, A. 2006. Creative cities: Conceptual issues and policy questions. Journal of Urban Affairs 28(1):1-17.

Scott, W. 2001. Institutions and Organizations. Thousand Oaks, CA: Sage.

Statistics Canada. 1991. 1991 Public Use Microdata File on Individuals. User Documentation. Ottawa: Statistics Canada.

— 1996. 1996 Public Use Microdata File on Individuals. User Documentation. Ottawa: Statistics Canada.

—. 2001. 2001 Public Use Microdata File on Individuals. User Documentation. Ottawa: Statistics Canada. 2006. 2006 Public Use Microdata File on Individuals. User Documentation. Ottawa: Statistics Canada.

Storper, M. 1997. The Regional World: Territorial Development in a Global Economy. New York: Guilford Press.

Veblen, T. 1904. The Theory of Business Enterprise. New York: Charles Scribner and Sons.

- 1914. Instinct of Workmanship and the State of the Industrial Arts. New York: Charles Scribner and Sons.

Yeats, M. 1998. The industrial heartland: Its changing role and internal structure, in Heartland and Hinterland: Geography of Canada, edited by L. McCann and A. Gunn. Toronto: Prentice Hall, pp. 109-45.

Yeung, H. 2005. The firm as social network: An organizational perspective. Growth and Change 36(3):307-28.

Zhao, J., D. Drew, T. Murray. 2000. Brain drain and brain gain: The migration of knowledge workers from and to Canada. Education Quarterly Review 6(3):8-35. 